\title{
Implementation of Instructions on the Prohibition of Use Policy Plastic Bags in Jayapura City in Pandemic Situation
}

\author{
Jems Pinder*, Mesak Rumsowek, Corinus Ye Mate, Ari Lucki Ansanay, Ilham, M. Zaenul Muttaqin \\ Department of Public Administration \\ Cenderawasih University \\ Papua, Indonesia \\ *jemspinder@gmail.com
}

\begin{abstract}
Implementation of the Mayor's Policy instructions on the Prohibition of the Use of Plastic Bags in modern liters such as minimarket hypermart and shops and other entrepreneurs in Jayapura City. Prohibiting the use of plastic bags is beneficial for developed and developing regions such as Jayapura City, because with the increase in population has an impact on increasing community needs, it can result in increased volume of plastic waste, which will adversely affect the community environment. The problem of this research was how the implementation of the Jayapura Mayor's policy on the prohibition of the use of plastic bags and what factors influenced the implementation of the policy in pandemic situation. While the purpose of this study was to find out and analyzed the implementation of policies as well as the factors that influenced policy implementation. The method used in this study was a qualitative research method where primary and secondary data were analyzed using the theory of Marille S. Grindle, the research result was the implementation of the Jayapura Mayor's policy instructions on the prohibition of using plastic bags that had been carried out by modern literary owners and entrepreneurs as well as society by not providing plastic bags anymore. Because all respondents said that plastic bags are materials that are difficult to decompose and damage the environment, this instruction became one of the things that is important for the life of the community and made a large contribution to entrepreneurs. While this situation, pandemic covid-19 make any degradation of uses plastic. The factors that influence the implementation of policies are adaptation to policies, initially the market compren because they have ordered plastic bags in large quantities and the government provides tolerance to spend the plastic bags with the condition not to order them again, until finally until now modern liters in the city of jayapura have implemented the mayor of jayapura's instructions on the ban on the use of plastic bags optimally.
\end{abstract}

Keywords-policy implementation, prohibition of use of plastic bags, Covid-19

\section{INTRODUCTION}

The garbage problem is still a national problem that has not been resolved. Based on its characteristics, plastic garbage has a wider impact. 3R Concept of The Ministry of Environment and Forestry (Reuse, Reduce, and Recycle) and other alternatives aimed at reducing plastic garbage by more than 1.9 million tons by 2019. However, these options have not been optimal without the assistance of all parties [1].

Law No.18/2008 concerning garbage management is a reference in garbage management. Several factors cause waste, namely: a. Population increase and changes in people's consumption designs. This issues in a higher volume, type, and characteristics of garbage. b. So far, garbage control techniques and methods are not running with environmental perspicacity; c. Garbage has become a national problem. There needs to be broad and integrated research from upstream to downstream regarding the economic occasions for garbage control; d. Garbage management requires legal certainty, clarity of responsibilities and authorities of the Government, regional government, as well as the role of the community and the business world so that garbage management can run proportionally, effectively, and efficiently.

Moreover, Law No.18/2008 concerning garbage control especially Plastic where is a material or something that is really needed by the community in their daily life, goods made from plastic, including plastic bottles, food and beverage wrappers, and plastic bags. Disproportionate use of plastic bags can have a big problematic effect. The risks of plastic garbage have an impact on humans, plants, animals, and environmental pollution because plastic needs years to decay [2]. The rapid development of the city of Jayapura has produced a compact population of Jayapura City, resulting in large population demands which can proceed to improve the amount of garbage then this can spread of a population.

The volume of garbage for residents of Jayapura City, Papua, in 2017 is 292 tons per day. In 2018, the volume of garbage from the city of Jayapura increased to 302 tonnes per day, and until now the population has continuously increased [3]. The effect of overloaded plastic using with increasing needs of the population and the level of public awareness that makes plastic bags in landfill have an impact if they are 
brought into rivers or streams and even the sea which can have negative consequences on the people on the riverbanks if there is high rainfall which will result in blockage of water flow and flooding. Of course, it can be dangerous for the people who live near the river.

Environmental impacts do not only occur in densely populated environments, but also marine areas. One of the findings of the bad effects of plastic garbage, namely the Papua Province Marine and Fisheries Service (DKP) established that most of the fish in the sea die from the poison of plastic garbage that is fed by fish because they smell similar to food. This happens because plastic garbage cannot be unraveled in a short time. Environmental contamination due to plastic garbage obstructs the ecosystem and marine biota, FX Mote in Jayapura

In 2020, 32 Local Governments have made laws for limiting garbage. In common, the regulations issued refer to single-use plastic garbage [4]. Along with the growth of the population and the level of consumption also grows plastic. In response to tackling the volume of garbage in the city of Jayapura, the Mayor of Jayapura took Instruction Number 1 of 2019 concerning the Ban of Using Plastic Bags. This policy is simultaneously implemented in traditional markets, supermarkets, minimarkets, stalls, shops, kiosks, and other places such as buying and selling transactions.

At the opening of 2020, the Corona Virus Disease 2019 (COVID-19) pandemic penetrated all living systems. From April 20 to May 5, 2020, the Oceanographic Research Center and Population Research Center LIPI published the outcomes of research linked to 'The Impact of large-scale social restrictions and WFH on Plastic Garbage in the JABODETABEK area' which presents the majority of Jabodetabek citizens do online shopping which leads to increase [5]. The amount of plastic garbage from package wrappers exceeds the amount of plastic garbage from the packaging purchased. Behavioral changes can occur because of understanding, the process of interaction with the environment with regard to certain objects is really necessary to recover from COVID-19 [6].

The goal of this research was to find out and investigate the implementation of the Mayor's Policy Instruction Number 1 of 2019 concerning the Banning of the Use of Plastic Bags in Jayapura City during the Covid-19 Pandemic.

\section{METHODS}

The research was a qualitative method with a descriptive approach so that it could present a summary of the object of a situation, especially the policy to prevent the use of plastic bags in Jayapura City. Specifically, the research location was taken at the Jayapura City Environment and Sanitation Service. Determination of subjects in this study cleaning employees, and the community. Type of field research was taken with an observational survey. Data analysis included reduction, data presentation to verification, and conclusion [7].

\section{RESULTS AND DISCUSSION}

\section{A. Implementation of the Prohibition on the Use of Plastic Bags}

Mayor's Instruction No.1/2019 is regarding the prohibition of the use of plastic bags. This instruction further controls how to prohibit the use of plastic bags in areas including areas where the volume of plastic garbage is increasing in the city of Jayapura.

1) Degree of policy change: Based on the change of the policy to prevent the use of plastic bags in Jayapura City, it proves that there has been a reduction of the land which is projected as a landfill. The target that is intended is the addition of a wider landfill. The Jayapura City government policy has great coordination with the Environment Agency regarding the policy of prohibiting the use of plastic bags. The lessening of land for landfills is due to population growth in Jayapura City. This requires synergy between environmental stability factors and population control [8].

The implementation of the policy to prohibit the use of bags in the city of Jayapura has agreed with market owners, shops, stalls, market vendors through socialization and circulating circulars about the prohibition of using plastic bags, and has obtained very positive responses from various institutions in this city, both government agencies, private organizations, nongovernment organization and the community itself because this policy is to address the volume of garbage and the diseased effects of the garbage itself, especially plastic bags in order to relinquish a clean and safe city of Jayapura in accordance with the vision and mission of the Mayor of Jayapura.

2) Powers, interests, and strategies of the actors involved: Concerning the power, interests, and actors included in performing the implementation of the prohibition against the use of plastic bags, especially in recent liters such as malls, hypermarkets, shops, stalls, and traditional markets as well as places where buying and selling transactions are provided in Jayapura City can be seen from public life always implementers of policies, and business people, such as owners, modern liters, shops, and tradesmen in traditional markets.

The power of business owners performs an essential role in realizing or fulfilling the policy issued by the Jayapura City government concerning the prohibition of using plastic bags. And the community as participants in this policy, the issue of economic interests is very dependent. The alliance has been using plastic bags for a long time because they discern plastic bags are waterproof and easy to use and do not spend like other shopping bags.

The issue of agreement from the community and business people in implementing the policy on the prohibition of using plastic bags is actually limiting its implementation. Therefore the issue of compliance has to include the community, entrepreneurs, and traders at the field level. This context validates the importance of an innovative and comprehensive 
garbage management design that is run with policy objectives [9].

Based on the results of the research, in implementing the ban on the use of plastic bags, information was provided through socialization and circulation of circular letters regarding the prohibition of using plastic bags to the public and entrepreneurs. This was executed in order to avoid losses from the policies issued by the Jayapura City government regarding the prohibition of using plastic bags.

On the other hand, without intensive information distribution, business owners will suffer losses when they have already ordered a large amount of plastic big bags. Information is one of the necessary points, especially for mini market owners, so the implementation of the policy to prevent the use of plastic bags is directly executed by the sales business owner by stopping ordering plastic bags. Mega Waena as one of the minimarkets that provides various housing requirements in Jayapura City has implemented this policy. Without support from business owners, the system to decrease plastic bags will continue to grow. Based on the statement of the Mega Waena supervisor, the policy issued by the Jayapura City government has been performed directly by the company so that no more buyers use plastic bags. This plastic bag ban policy is also for the common good. Basically, the reduction of Plastic Waste still creates various problems. This is because the socialization of single-use plastics has not been maximally achieved [10].

However, Jayapura City shows a different thing. One of the government's strategies is to include the role of a minimarket to support the policies issued by the Mayor of Jayapura. The minimarket provides paid alternative shopping bags. People who do not have time to bring shopping bags from home or do not know about the policies issued by the mayor can take benefit of the paid alternative shopping bags that have been provided at the cashier. Hence, there is an educational side, many people have followed the rules set through policies. Based on the results of these interviews, it can be understood that the positive enthusiasm of market owners and the community in accepting the policy of prohibiting the use of plastic bags. Because with the prohibition on the use of plastic bags. The market gets advantages because they no longer provide plastic bags and the people also have consciousness in implementing policies. Currently, Jayapura City has a very high population. The rule to prevent the use of plastic bags is very crucial because the interests and necessities of the residents of Jayapura are not the same. This will have an impact on the growth of garbage in the City.

\section{B. Jayapura City Garbage Management during the Covid-19 Pandemic}

The Covid-19 should be a momentum for the legislative and executive organizations to improve the garbage management system so that it will be better prepared for similar crashes in the future [11]. Medical trash that is not properly handled will be a new source of Covid-19 transmission.
1) Medical plastic waste policy design: Throughout the Covid-19 pandemic, the design of plastic waste management policies in various cities experienced a shift. In common, plastic garbage comes from medical trash. In connection with this problem, Benhur Tomi Mano as the Mayor of Jayapura delegated the handling of medical garbage to the Regional Health Laboratory under the shelter of the Papua Province, [12]. Regional Health Laboratories tackle Covid-19 medical garbage with a scheme. Besides being burned, garbage is placed in a special box provided at the public health then crushed using an incinerator or small solid garbage processing equipment.

2) Handling of commercial plastic garbage and household garbage during a pandemic: Since the Covid-19 pandemic, the amount of financial garbage has decreased. In Bandung City, the mayor's policies have been well run by the public. The reduction of garbage cannot be separated from the policy of closing shopping centers for several weeks [13].

Community activities that are mostly used inside the house in Jayapura City have succeeded in a decrease the garbage in public locations. However, the garbage problem reveals something different. Activities in the house second household garbage production to increase. The Jayapura City Environment and Sanitation Service noted that the volume of household rubbish increased by 10 percent during the Covid-19 pandemic. The total daily waste before the epidemic was 313 tons per day.

Based on the information from Ketty Kailola as a Head of the Environment and Sanitation Service for the City of Jayapura, the waste problem is increasing in Jayapura City due to the increasing use of online ordering services. The volume of waste deported to landfills reaches 4,000 tonnes per month during the pandemic period [14]

3) Community support: One manifestation of the success of tackling plastic garbage in Jayapura City is by approaching the Adipura award five times [14]. As explained by the research sources, this matter needs to be maintained by the City of Jayapura as a form of commitment to solve the garbage. This achievement cannot be separated from participation.

One of the programs originated by the Jayapura city government is to empower the community's creativity. In the context of plastic garbage, in 2019, the City Government held an art competition for plastic garbage. These activities motivate public recognition of environmental problems to increase.

During a pandemic, one form of public assistance was to run street campaigns. This action was initiated by an environmental observer community that included several groups such as the State Civil Servant, students, housewives, student doctor candidates, school children including social media activists such as YouTubers [15]. The campaign was taken on the highway with standard health protocols. Each participant brings a board containing creative messages using 
critical and easy-to-understand millennial language which aims to spark public awareness of garbage issues.

\section{CONCLUSION}

Based on the results of the research, there is a reduction of land for landfills due to population growth in Jayapura City. So it needs synergy between environmental protection factors and population control. The implementation of the ban on the use of plastic bags was equipped with information through socialization and circulation of a circular concerning the limitation on the use of plastic bags to the public and minimarket entrepreneurs in the city of Jayapura. During the Covid-19 Pandemic, medical garbage was managed by the Regional Health Laboratory under the auspices of the Papua Province. Community activities that are mostly utilized inside the house in Jayapura City have resulted in a decrease in the garbage in public locations. however, in the household sector, the waste problem is increasing due to the increasing use of online ordering services. Policy support begins from public concern for environmental aspects, eliminating the use of plastic bags by minimarket entrepreneurs, shop owners, and small shops.

\section{REFERENCES}

[1] P. Purwaningrum, "Upaya Mengurangi Timbulan Sampah Plastik Di Lingkungan," Indonesian Journal of Urban and Environmental Technology, vol. 8, pp. 141-147, 2016.

[2] L. P. Yuliadi, I. Nurruhwati, and S. Astuty, "Optimalisasi pengelolaan sampah pesisir untuk mendukung kebersihan lingkungan dalam upaya mengurangi sampah plastik dan penyelamatan Pantai Pangandaran," Jurnal Pengabdian Kepada Masyarakat, vol. 1, 2017.

[3] A. Wisanggeni G, "Volume sampah di Kota Jayapura terus bertambah, bank sampah bisa jadi solusi," Jubi.co.id, 2019. [Online]. Retrieved from: https://jubi.co.id/volume-sampah-di-kota-jayapura-terusbertambah-bank-sampah-bisa-jadi-solusi/.

[4] N. Anugrah, KLHK: Indonesia Memasuki Era Baru Pengelolaan Sampah. Jakarta: KLHK, 2020.

[5] LIPI, Peningkatan Sampah Plastik dari Belanja Online dan Delivery Selama PSBB. Lembaga Ilmu Pengetahuan Indonesia, 2020.

[6] V. Amalia, E. P. Hadisantoso, I. R. Wahyuni, and A.M. Supriatna, Penanganan limbah infeksius rumah tangga pada masa wabah COVID19. Bandung: UIN Sunan Gunung Djati, 2020.

[7] L.J. Moleong, Metodologi Kualitatif. Bandung: PT Remaja Rosdakarya, 2005 .

[8] I. Wardi, I. Laksmiwati, I. Gunadi, and A. As-syakur, "Dampak Pertumbuhan Penduduk Terhadap Lingkungan Dan Budaya Subak: Studi Kasus Di Kabupaten Tabanan Provinsi Bali," Jurnal Bumi Lestari, vol. 14, pp. 110-124, 2014.

[9] A. Marlina, "Tata Kelola Sampah Rumah Tangga melalui Pemberdayaan Masyarakat dan Desa di Indonesia," Jurnal Ilmu Pendidikan (JIP) STKIP Kusuma Negara Jakarta, vol. 11, pp. 125-144, 2020.

[10] B.N. Avianto, "Implementasi Peraturan Walikota Bogor Nomor 61 Tahun 2018 Tentang Pengurangan Kantong Plastik (Studi di Mall Wilayah Utara Kota Bogor)," Syntax Literate; Jurnal Ilmiah Indonesia, vol. 5, pp. 32-42, 2020.

[11] T. Prasetiawan, "Permasalahan Limbah Medis Covid-19 Di Indonesia," Info Singkat, vol. 12, 2020.

[12] Z. Zulkifli, "Upaya Pemkot Jayapura Menangani Pandemi Covid-19," Pasificpos.com, 2020. [Online]. Retrieved from: https://www.pasificpos.com/upaya-pemkot-jayapura-menanganipandemi-covid-19/.

[13] M.F. Ridwan, "Pandemi Covid-19, Sampah Komersil di Bandung Berkurang," Republika, 2020. [Online]. Retrieved from: https://republika.co.id/berita//q83ush459/pandemi-covid-19-sampahkomersil-di-bandung-berkurang

[14] D. Wulandari, "Pandemi korona, volume sampah rumah tangga di Kota Jayapura meningkat," Jubi.co.id, 2020. [Online]. Retrieved from: https://jubi.co.id/papua-sampah-rumah-tangga/. [Accessed: 24-Jul2020].

[15] A. Ade, "Kreatif, Pemuda Ini Sebar Pesan Virus Corona di Lingkaran Abepura," ceposonline.com, 2020. [Online]. Retrieved from: https://www.ceposonline.com/2020/02/23/kreatif-pemuda-ini-sebarpesan-virus-corona-di-lingkaran-abepura/. [Accessed: 24-Jul-2020]. 